\section{OPEN ACCESS}

Edited and reviewed by: Vincenzo Tufarelli,

University of Bari Aldo Moro, Italy

*Correspondence:

Zora Váradyová

varadyz@saske.sk

Specialty section:

This article was submitted to Animal Nutrition and Metabolism,

a section of the journal

Frontiers in Veterinary Science

Received: 29 January 2021 Accepted: 01 February 2021

Published: 17 February 2021

Citation:

Petrič D, Mravčáková D, Kucková K Kišidayová S, Cieslak A,

Szumacher-Strabel $M$, Huang $H$,

Kolodziejski P, Lukomska A,

Slusarczyk S, Čobanová K and Váradyová Z (2021) Corrigendum: Impact of Zinc and/or Herbal Mixture on Ruminal Fermentation, Microbiota, and Histopathology in Lambs.

Front. Vet. Sci. 8:660794

doi: 10.3389/fvets.2021.660794

\title{
Corrigendum: Impact of Zinc and/or Herbal Mixture on Ruminal Fermentation, Microbiota, and Histopathology in Lambs
}

\begin{abstract}
Daniel Petrič ${ }^{1}$, Dominika Mravčáková ${ }^{1}$, Katarina Kucková ${ }^{1}$, Svetlana Kišidayová ${ }^{1}$ Adam Cieslak², Malgorzata Szumacher-Strabel ${ }^{2}$, Haihao Huang ${ }^{2}$, Pawel Kolodziejski ${ }^{3}$, Anna Lukomska ${ }^{4}$, Sylwester Slusarczyk ${ }^{5}$, Klaudia Čobanová ${ }^{1}$ and Zora Váradyová ${ }^{\text {* }}$

${ }^{1}$ Institute of Animal Physiology, Centre of Biosciences of the Slovak Academy of Sciences, Košice, Slovakia, ${ }^{2}$ Department of Animal Nutrition, Poznan University of Life Sciences, Poznan, Poland, ${ }^{3}$ Department of Animal Physiology, Biochemistry and Biostructure, Poznan University of Life Sciences, Poznan, Poland, ${ }^{4}$ Department of Preclinical Sciences and Infectious Diseases, Poznan University of Life Sciences, Poznan, Poland, ${ }^{5}$ Department of Pharmaceutical Biology and Botany, Wroclaw Medical University, Wroclaw, Poland
\end{abstract}

Keywords: bacteria, ciliated protozoa, hematological profiles, histology, phytochemicals, sheep

\section{A Corrigendum on}

Impact of Zinc and/or Herbal Mixture on Ruminal Fermentation, Microbiota, and Histopathology in Lambs

by Petrič, D., Mravčáková, D., Kucková, K., Kišidayová, S., Cieslak, A., Szumacher-Strabel, M., et al. (2021). Front. Vet. Sci. 8:630971. doi: 10.3389/fvets.2021.630971

In the original article, there was a mistake in Table 2 and Table 3 as published. In the columns under $\mathrm{m} / \mathrm{z}[\mathrm{M}-\mathrm{H}]$ - in all expressions separating numbers from decimals, there should be dots (.) not a slash (/). The corrected Tables 2 and 3 appear below.

The authors apologize for this error and state that this does not change the scientific conclusions of the article in any way. The original article has been updated.

Copyright @ 2021 Petrič, Mravčáková, Kucková, Kišidayová, Cieslak, Szumacher-Strabel, Huang, Kolodziejski, Lukomska, Slusarczyk, Cobanová and Váradyová. This is an open-access article distributed under the terms of the Creative Commons Attribution License (CC BY). The use, distribution or reproduction in other forums is permitted, provided the original author(s) and the copyright owner(s) are credited and that the original publication in this journal is cited, in accordance with accepted academic practice. No use, distribution or reproduction is permitted which does not comply with these terms. 
TABLE 2 | Concentrations of the main bioactive compounds in medicinal herbs ( $g / k g ~ D M)$.

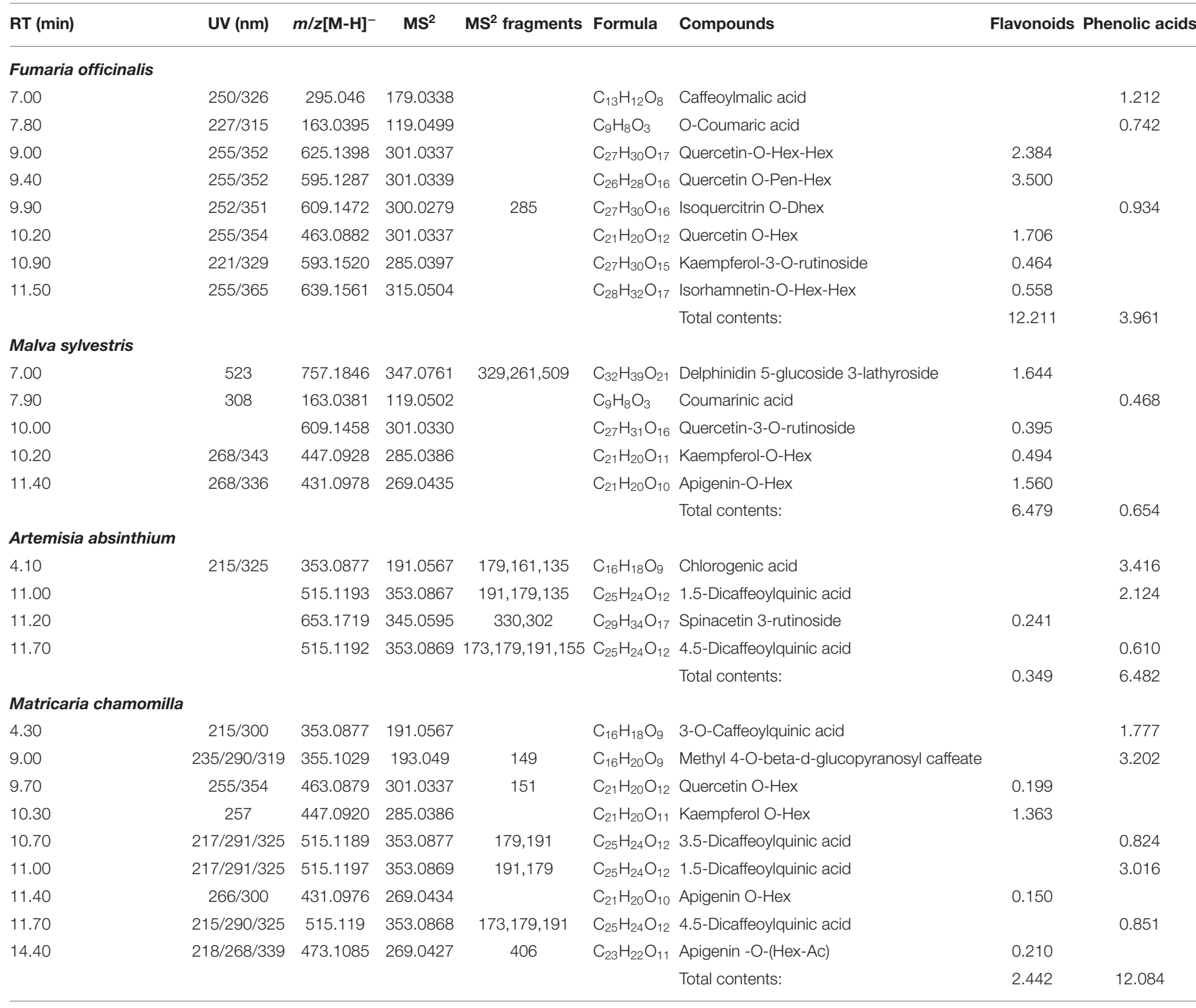

TABLE 3 | Concentrations of the main alkaloids in Fumaria officinalis ( $/ \mathrm{kg} \mathrm{DM}$ ).

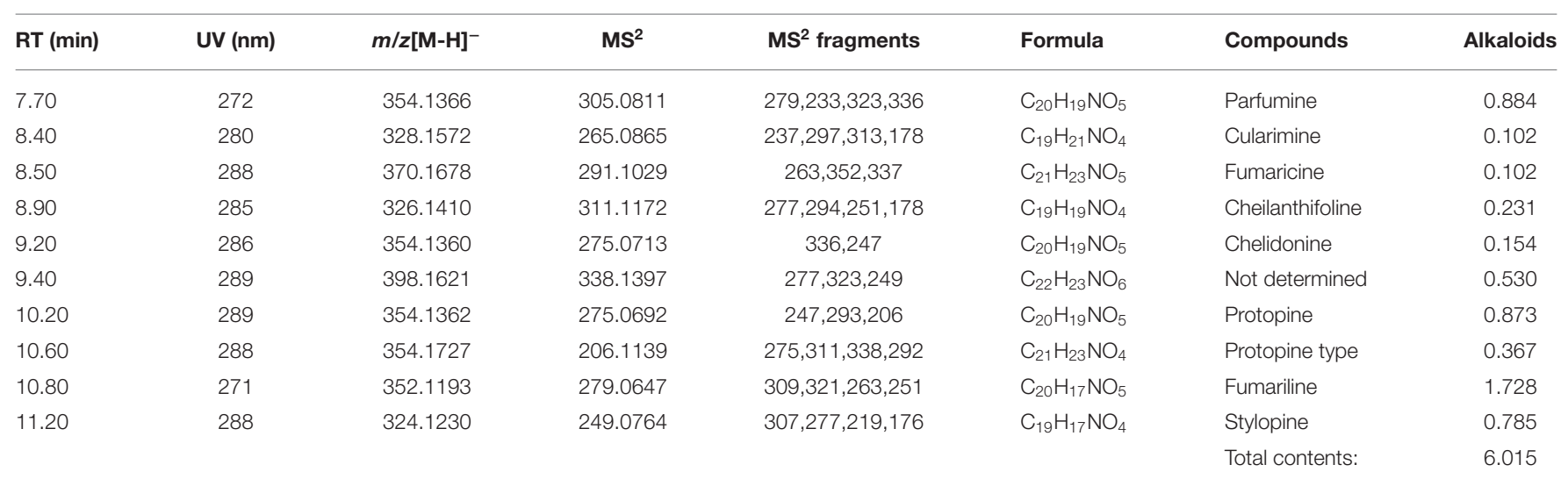

